\title{
Identifying the Main Technological Parameters for Bio-Product Exemplified by Bacteriophage Xanthomonas campestris pv. campestris Kl34-UTSAV
}

\section{Maiorov Pavel', Feoktistova Natalya A. ${ }^{1}$, Vasilyev Dmitry A. ${ }^{1}$, Mallyamova Elvira Sh. ${ }^{1}$, Nafeev Alexander A. ${ }^{1}$, Toigildin Alexander L. ${ }^{1 *}$, Toigildina Irina A. ${ }^{1}$, Obukhov Igor L. ${ }^{2}$, Shmorgun Boris I. ${ }^{3}$}

'Ulyanovsk State Agrarian University named after P.A.Stolypin, Ulyanovsk (Russian Federation)

${ }^{2}$ All-Russian Research Institute of Veterinary sanitary, Hygiene and Ecology, Moskau (Russian Federation)

${ }^{3}$ Russian State Center of Quality and Standardization Medicines for Animals and Feed, Moskau (Russian Federation)

Study Area: Ulyanovsk, Russia

Coordinates: $54^{\circ} 19^{\prime} \mathrm{N} ; 48^{\circ} 22^{\prime} \mathrm{E}$

Key words: Biopreparation, Plant disease

\section{Introduction:}

PBacterial diseases of plants are the important reason for the reduction in agricultural yield, as till date, there is no effective means of controlling them. Vascular bacteriosis of crucial, caused by bacteria Xanthomonas campestris pv. campestris, affects almost all known plants, referring to the family crucial (Jensen et al., 2010; Ignatov et al., 2016). Standard means of control of given diseases do not provide satisfactory control of diseases, especially when weather conditions foster spread of agents (Massomo et al., 2004; Francisco et al., 2011). Nowadays bacteriophage appliance for identification and control of agents of bacterial diseases of plants is an invasive stream. Therefore bacteriophages can be used as an effective antibacterial measure (Clokie et al., 2011; Renu et al., 2017). The use of phage and phage identification is one of the most attractive alternatives of existing methods Bacteriophages are the viruses, which specifically infect bacteria, their reduplication leads to lysis of their bacterial host and release of the new- formed phage particles. Phage therapy was not studied for bacteria Xanthomonas campestris pv. campestris, however, there are vast data available regarding the use of given methods for other bacteria (Loc-Carrillo \& Abedon, 2011; Jones et al., 2012; Balogh et al., 2018).

The appliance of phage biopreparations in different methods (including the reaction of phage titer growth)

\section{Abstract}

Experiments to identify the best purifying method of bacteriophage from the production culture of bacteria was done. The temperature and trichloromethane influence, and also filtration of suspension through a membrane filter with different pore sizes were distinguished. It is established that suspension purifying from bacterial cells by filtration through membrane filters with a pore size of 0.22 micron turn out the best purification method. Under the given time optimum ratio of the result (lytic activity of bacteriophage) and hourage were obtained. The selection of the optimum ratio of phage and bacterial culture for cultivation showed that the best ratio are 1:2 and 1:3. Under the given parameters we obtained similar results. As optimum temperature of cultivation of bacteriophage temperature of $20-32^{\circ} \mathrm{C}$ was established, at which bacteriophage activity is preserved.

allows to exert control and analyze the quantitative and qualitative composition of isolated bacteria, it takes less time unlike classical bacteriological methods (Feoktistova, et al., 2018). Phage diagnosis as one of the methods of indication and identification allows to determine the affiliation of studied bacteria not only with specific genus but to the species and even phage var (Chugunova \& Tatarnikova, 2016).

However, it is important to note that the selection of bacteriophages forming part of biopreparation for indication and identification of bacteria, requires their deep research and determination of optimum interoperation specifications of phage-bacteria with the aim to minimize the development of their resistance of bacteria to the used bacteriophages (Jones et al., 2012).

The aim of this study was to select an optimal technological parameters for biopreparation production on the basis of earlier isolated bacteriophages.

\section{Materials and methods:}

For this piece of work 10 isolates of bacteriophages X.campestrispv. campestris (Kly-ULSAU, Klı-ULSAU, Kl20-ULSAU, Kl21-ULSAU, Kl22-ULSAU, Z2-ULSAU, Z4-ULSAU, Z7-ULSAU, Kl33-ULSAU, Kl34-ULSAU, S4-ULSAU), isolated from samples of soil and cabbage with the signs of damage from black rot from the fields of 
Ulyanovsk and Ulyanovsk region (Department of Microbiology, Virology, Epizootiology and Veterinary \& Sanitary expertise of Ulyanovsk, SAU). As production we used strain X.campestris pv., campestris Xc2, considering that it had typical properties for such species of bacteria, and also it had the best parameters of growth performances for 24 hours (from $1.6 \times 10^{8} \mathrm{~m} . \mathrm{k} . / \mathrm{ml}$ ). Additionally to increase reliability in a particular experiment we used bacterial strains B-570 and Xc1.

Mediums and reagents: Bacteriological agar (RMA «Mediums», Makhachkala), dry enzymic peptone (HiMedia), tryptone (HiMedia), yeastrel (HiMedia), medium LB (tryptone - $10 \mathrm{~g} / \mathrm{l}$, yeastrel - $5 \mathrm{~g} / \mathrm{l}, \mathrm{NaCl}$ - $10 \mathrm{~g} / \mathrm{l}$ ), sodium chloride (LLC «UlChem»), glucose (HiMedia).

Instruments and equipment: Laaboratory bacteriological ware, heated bath, mercury thermometer, distiller, siccative sterilizing cabinet SSC - 8o, digester GK100-3, minus, and domestic fridges, thermostat-8oM-2. The research was carried out on the basis of the given and battle-tested method of members of the above-mentioned departments (Zolotukhin, 2007; Feoktistova et al., 2018).

\section{Results and Discussion :}

The main technological parameters of production and control of phage biopreparations are such parameters as qualitative ratio of phage to bacterial crop, optimum ratio of passage time to phage activity, the temperature of cultivation to the purifying method of bacteriophage from production culture of bacteria without change of its main biological properties.

The best purifying method of bacteriophage from production culture of bacteria was determined by studying the stability of bacteria to the temperature (comprised between $56-68^{\circ} \mathrm{C}$ ) and to trichloromethane (in concentration 1:5, 1:10 \& 1:20). Besides we carried out a range of experiments with filtration of studied suspension through membrane filters using different pore sizes (o.1 0.45 micron). All presented parameters were selected by proper measurements. As a bacterial test-cultures, we used strains of bacteria X.campestris pv. campestris B-570, Xc1 and Xc2.

For the study of stability of bacteria X.campestris $p v$. campestris to the temperature test-tube with the suspension of bacterial culture in concentration of 107-108 $\mathrm{m} . \mathrm{k} . / \mathrm{ml}$ were heated on a heated bath at the temperature of $56-68^{\circ} \mathrm{C}$ at $2^{\circ} \mathrm{C}$ intervals during $10-30 \mathrm{~min}$. at every $10 \mathrm{~min}$. intervals. After bacterial inoculation, on Petri dishes, it was seeded and during 48 hrs we registered growth and absence of growth of studied strains. The results of conducted research are shown in picture 1.

Received data indicate that heating of bacterial cultures during 10 minutes intervals does not give necessary results, as all studied strains showed stability to the temperature (in the range of temperatures $56-68^{\circ} \mathrm{C}$ ) in this time span (table-1). While heating during 20 minutes, strains Xc1, Xc2 showed stability to temperatures down to $62^{\circ} \mathrm{C}$ (Plate-1), strain B-570 was not stable at the temperatures of $60^{\circ} \mathrm{C}$ (table-2). At exposition time equal to $30 \mathrm{~min}$. all studied strains showed stability to temperatures $56^{\circ} \mathrm{C}$ (table-3). Thus we consider optimum temperature for the inactivation of bacteria X.campestris pv. campestris is $62^{\circ} \mathrm{C}$ at exposition time of $20 \mathrm{~min}$. Wyrefused of heating during $30 \mathrm{~min}$., as during reduction of tempera-tures by various degrees time of the experiment is raising by half.

Table-1: Stability of bacteria X.campestris pv. campestris to the temperature $(\mathrm{oC})$ (Exposition time 10 minutes)

\begin{tabular}{llllllll}
\hline Temp/Strain & $56^{\circ} \mathrm{C}$ & $58^{\circ} \mathrm{C}$ & $60^{\circ} \mathrm{C}$ & $62^{\circ} \mathrm{C}$ & $64^{\circ} \mathrm{C}$ & $66^{\circ} \mathrm{C}$ & $68^{\circ} \mathrm{C}$ \\
\hline $\mathrm{B}-570$ & + & + & + & + & + & + & + \\
$\mathrm{Xc1}$ & + & + & + & + & + & + & + \\
$\mathrm{Xc2}$ & + & + & + & + & + & + & +
\end{tabular}

Table-2: Stability of bacteria X.campestris pv. campestris to the temperature (oC) (Exposition time 20 minutes)

\begin{tabular}{llllllll}
\hline Temp/Strain & $56^{\circ} \mathrm{C}$ & $58^{\circ} \mathrm{C}$ & $60^{\circ} \mathrm{C}$ & $62^{\circ} \mathrm{C}$ & $64^{\circ} \mathrm{C}$ & $66^{\circ} \mathrm{C}$ & $68^{\circ} \mathrm{C}$ \\
\hline $\mathrm{B}-57 \mathrm{O}$ & + & + & - & - & - & - & - \\
$\mathrm{Xc1}$ & + & + & + & - & - & - & - \\
$\mathrm{Xc2}$ & + & + & + & - & - & - & - \\
\hline
\end{tabular}

Table-3: Stability of bacteria X.campestris $p v$. campestris to the temperature (oC) (Exposition time 30 minutes)

\begin{tabular}{llllllll}
\hline Temp/Strain & $566^{\circ} \mathrm{C}$ & $58{ }^{\circ} \mathrm{C}$ & $60^{\circ} \mathrm{C}$ & $62^{\circ} \mathrm{C}$ & $64^{\circ} \mathrm{C}$ & $66^{\circ} \mathrm{C}$ & $68{ }^{\circ} \mathrm{C}$ \\
\hline B-570 & + & - & - & - & - & - & - \\
Xc1 & + & - & - & - & - & - & - \\
Xc2 & + & - & - & - & - & - & - \\
\hline
\end{tabular}

Table-4: Sability of bacteria X.campestris $p v$. campestris to the thrichloromethane depending on concentration \& exposure time

Temp Concentraion $1 / 5$ Concentraion $1 / 10$ Concentraion $1 / 20$

\begin{tabular}{|c|c|c|c|c|c|c|c|c|c|}
\hline & $10^{*}$ & $20^{*}$ & $30 *$ & $10^{*}$ & $20^{*}$ & $30^{*}$ & $10^{*}$ & $20^{*}$ & $30^{*}$ \\
\hline B-570 & + & - & - & + & - & - & - & - & $-\quad \stackrel{g}{=}$ \\
\hline Xc1 & + & + & - & + & - & - & - & - & - \\
\hline$X_{c 2}$ & + & - & - & + & - & - & + & - & - \\
\hline
\end{tabular}

Study of bacteria stability Xanthomonas campestris $p v$. campestris to trichloromethane was carried out in the following way. Into test-tubes with the suspension of bacterial cultures in a concentration of 107-108m.k./mlwe added trichloromethane in the concentration of $1 / 5,1 / 10$ or $1 / 20$, after we shook the test-tube actively during 5,15 and 25 $\mathrm{min}$. Thus exposition time was 10, 20, and $30 \mathrm{~min}$. at the end of time exposures, the supernatant was selected and seeded on Petri dishes. seedings were cultivated at a temperature of $28^{\circ} \mathrm{C}$ during $48 \mathrm{hr}$. The results of the conducted experiments are shown in table-4.

Studied bacteria showed stability to the influence of thrichloromethane in concentration $1 / 5$ for 20 minutes, in a concentration of $1 / 10$ during 10 minutes, and in a concentration of $1 / 20$ for 10 minutes. We considered that optimum parameters of time of conducted experiment and 
RESEARCH ARTICLE

Table-5: Lytic activity of bacteriophage after purifying of suspension from bacteria by few methods

\begin{tabular}{|c|c|c|c|c|}
\hline Bacteriophage & $\begin{array}{l}\text { Throchlorometh. } \\
\text { (1/10, } 20 \text { conc. })\end{array}$ & $\begin{array}{l}\text { Temperature } \\
62^{\circ} \mathrm{C}, 20 \text { min. }\end{array}$ & $\begin{array}{l}\text { Filtration, Pore } \\
\text { size o.1 micron }\end{array}$ & $\begin{array}{l}\text { Filtration, Pore } \\
\text { size } 0.22 \text { micron }\end{array}$ \\
\hline K19ULSAU & $1.3 X_{10}^{8} \pm 0.1 X_{10}^{8}$ & $1.3 X_{10}^{7} \pm 0.1 X_{10}^{7}$ & $1.5 X_{10}^{6} \pm 0.2 X_{10}^{6}$ & $1.8 \mathrm{X}_{10} 0^{8} \pm 0.1 \mathrm{X}_{10}^{8}$ \\
\hline K113UL SAU & 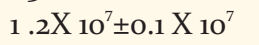 & $1.2 X_{10}^{6} \pm 0.1 X_{10}^{6}$ & $1.0 \mathrm{X} 10^{6}+0.1{\mathrm{X} 10^{6}}^{6}$ & 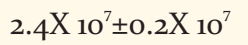 \\
\hline K120UL SAU & $1.1 X_{10}^{7} \pm 0.2 X_{10}^{7}$ & $1.1 \mathrm{X}_{10^{6} \pm 0.2 \mathrm{X}_{10}}{ }^{6}$ & $1.3 X_{10^{5}} \pm 0.2 X_{10^{5}}$ & $1.2 X_{10^{7} \pm 0.1} X_{10}^{7}$ \\
\hline K121ULSAU & $1.2 \mathrm{X}_{10^{8}} \pm 0.1 \mathrm{X}_{10^{8}}$ & $1.0 X 10^{8} \pm 0.2 X_{10}^{8}$ & $1.3 X_{10}^{7} \pm 0.1 X_{10}^{7}$ & $1.4 \mathrm{X}_{108 \pm 0.1}{\mathrm{X} 10^{8}}^{8}$ \\
\hline K122ULSAU & $1.3 X_{10}^{6} \pm 0.1 X_{10}^{6}$ & $1.5 \mathrm{X}_{10^{5} \pm 0.1} \mathrm{X}_{10^{5}}$ & $1.1 X_{10}^{5} \pm 0.2 X_{10}^{5}$ & $1.8 X_{10}^{6}+0.3 X_{10}^{6}$ \\
\hline Z2ULSAU & $1.8 \times 10^{5} \pm 0.3 \times 10^{5}$ & $1.4 X_{10^{5} \pm 0.2} X_{10^{5}}$ & $1.4 \mathrm{X}_{10^{5} \pm 0.1}{\mathrm{X} 10^{5}}^{5}$ & $2.5 \mathrm{X} 10^{6} \pm 0.2 \mathrm{X} 10^{6}$ \\
\hline $\mathrm{Z}_{4} \mathrm{ULSAU}$ & $1.6 \mathrm{X}_{10^{6} \pm 0.2 \mathrm{X} 10^{6}}$ & $1.2 X_{10^{6}} \pm 0.3 X_{10} 0^{6}$ & $1.1 \mathrm{X}_{10^{6} \pm 0.2 \mathrm{X}_{10}}{ }^{6}$ & $2.1 \mathrm{X}_{10^{7} \pm 0.4 \mathrm{X}_{10}}$ \\
\hline Z7ULSAU & 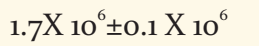 & $1.5 X_{10}^{6} \pm 0.2 X_{10}^{6}$ & $1.2 X_{10^{5}} \pm 0.2 X_{10^{5}}$ & 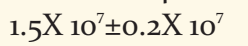 \\
\hline K133ULSAU & $1.1 X_{10} 0^{7} \pm 0.1 X_{10}^{7}$ & $1.2 X_{10}^{6} \pm 0.2 X_{10}^{6}$ & 1. $6 \mathrm{X} 10^{5} \pm 0.5 \mathrm{X} 10^{5}$ & $3.4 X_{10}^{7} \pm 0.1 \times 10^{7}$ \\
\hline K134ULSAU & $1.5 \mathrm{X}_{10^{7} \pm 0.2 \mathrm{X}_{10}}$ & $1.2 X_{10^{7}}^{7} \pm 0.1 X_{10}^{7}$ & $1.8 X_{10^{6} \pm 0.4 X 10^{6}}$ & $2.2 \mathrm{X}_{10^{8} \pm 0.1} \mathrm{X}_{10^{8}}$ \\
\hline $\mathrm{S}_{4} \mathrm{UL}$ SAU & 1.oX $10^{7} \pm 0.1 X_{10^{7}}$ & $1.4 X_{10}^{7} \pm 0.1 X_{10}^{7}$ & $1.5 \mathrm{X} 10^{6} \pm 0.2 \mathrm{X}_{10^{6}}$ & $1.5 \mathrm{X}_{10^{8}+0.3 \mathrm{X}_{10}^{8}}$ \\
\hline
\end{tabular}

Ambient Science, 2020: Vol. 07(1); 07-10 DOI:10.21276/ambi.2020.07.1.ra03

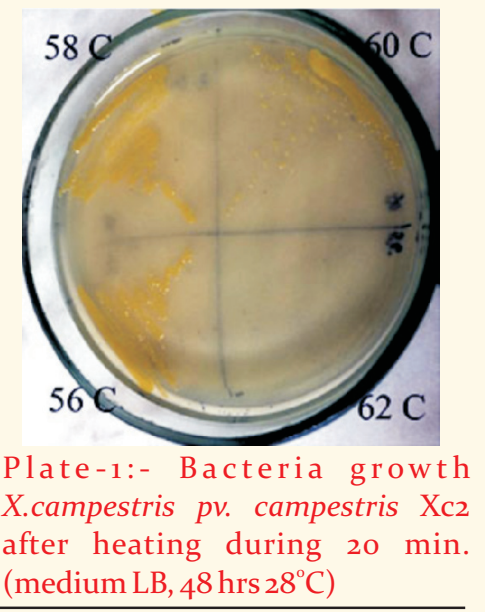

quantity of expended reagents are the time of exposition 20 minutes and concentration of thrichloromethane 1/10.

Table-6: Dependence of bacteriophage titer on passage time (in terms of phage K134-ULSAU)

\begin{tabular}{|c|c|c|}
\hline $\begin{array}{l}\text { Bacteriophage } \\
\text { bacteriophage }\end{array}$ & Passage time. hours & $\begin{array}{l}\text { Lytic activity of } \\
\text { By Gratia. BFU/ml }\end{array}$ \\
\hline \multirow{8}{*}{ K134-ULSAU } & 8 & $1.2 X_{10}^{4} \pm 0.2 X_{10}^{6}$ \\
\hline & 12 & $1.3 X_{10}^{5} \pm 0.2 \times 10^{7}$ \\
\hline & 16 & $1.5 \mathrm{X}_{10^{6} \pm 0.4 \mathrm{X}_{10}}$ \\
\hline & 20 & 1. $0 \mathrm{X}_{10^{7} \pm 0.2 \mathrm{X}_{10}^{8}}$ \\
\hline & 24 & $2.4 \mathrm{X}_{10^{8} \pm 0.1 \mathrm{X}_{10}^{8}}$ \\
\hline & 28 & $3.4 X_{10}^{8} \pm 0.2 X_{10}^{8}$ \\
\hline & 32 & $1.1 X_{10}^{8} \pm 0.1 X_{10}^{8}$ \\
\hline & 36 & $3.9 \times 10^{7} \pm 0.2 X_{10}^{7}$ \\
\hline
\end{tabular}

Table 7 - Dependence of bacteriophage titer on quantity of production culture of bacteria $X$. campestris $v$. campestris Xc2 (in terms of phage K134-ULSAU)

Quantity of added indicator culture $\mathrm{ml}$ on $0.2 \mathrm{ml}$ phage

\begin{tabular}{lllll}
0.2 & 0.4 & 0.6 & 0.8 & 1.0 \\
\hline $1.6 \times 10^{7} \pm$ & $1.1 \times 10^{8} \pm$ & $2.3 \times 10^{8} \pm$ & $2.1 \times 10^{7} \pm$ & $3.3 \times 10^{6} \pm$ \\
$0.1 \times 10^{7}$ & $0.2 \times 10^{8}$ & $0.3 \times 10^{8}$ & $0.1 \times 10^{7}$ & $0.2 \times 10^{6}$ \\
\hline
\end{tabular}

Table-8: Optimum temperature parameter of cultivation of bacteriophage during 24 hours (in terms of phage K134-ULSAU)

\begin{tabular}{lccccccc}
\hline Phage & $12{ }^{\circ} \mathrm{C}$ & $16^{\circ} \mathrm{C}$ & $20^{\circ} \mathrm{C}$ & $24^{\circ} \mathrm{C}$ & $28^{\circ} \mathrm{C}$ & $32^{\circ} \mathrm{C}$ & $36^{\circ} \mathrm{C}$ \\
\hline B-570 & - & - & + & + & + & - & -
\end{tabular}

Further experiments with the aim to study influence of earlier described methods of inactivation bacteria on lytic activity bacteriophages and comparison of given methods with a filtrationthrough membrane filters with the pore size of 0.1 micron and 0.22 micron were carried out. It should be pointed out that we didn't use membrane filters with pore size 0.45 micron as after filtration we noted the growth of the bacterial culture.

In test-tubes containing $4.5 \mathrm{ml}$ of culture fluid LB, targetted bacteriophage was seeded $(0.2 \mathrm{ml})$ with master seed strain of bacteria X.campestris pv. campestris Xc2 ( 0.2 $\mathrm{ml}$ ) and cultivated at the temperature of $28^{\circ} \mathrm{Cduring} 24$ hours. After that we carried out handling of suspension by thrichloromethane, temperature, and filtration through membrane filters with pore size 0.1 and 0.22 micron. Further lytic activity of studied bacteriophage was determined by the agar-layer method.

While identifying the best method of purifying suspension from bacterial cells is filtration through membrane filters with a pore size of 0.22 micron. During the use of filters with the pore size of o.1 micron, a decrease of lytic activity of studied bacteriophages was evidenced (in specif ic cases from 108 to $106 \mathrm{BFU} / \mathrm{ml}$ ). It is possible that the reason for this phenomenon is quick pore impurity that led to a decrease in the carrying capacity of filters. Treatment by temperature also had affected lytic activity in a negative way almost on all studied bacteriophages (exception is bacteriophage $\mathrm{Kl} 21-\mathrm{ULSAU})$. More close results to filtration (pore size 0.22 micron) were recorded during treatment of thrichloromethane, however, at specif ic bacteriophages we observed a noticeable reduction of lytic activity (Z2-ULSAU, Z4-ULSAU, Z7-ULSAU, $\mathrm{Kl}_{34}$-ULSAU, $\mathrm{S}_{4}$-ULSAU). In this view as the most acceptable method of purifying suspension from bacteriophage cells we consider filtration through membrane filters with pore size 0.22 micron. This method will be used in further experiments.

The following stage of our research was on the determination of optimum ratio of passage time and bacteriophage activity, for this aim, we added $0.2 \mathrm{ml}$ of production culture of bacteriophage X.campestris $p v$. campestris Xc2 and $0.2 \mathrm{ml}$ of studied bacteriophage into test tubes with liquid medium. Concurrently, we set control test tubes of the production culture of bacteria and separately of bacteriophage. Cultivation was carried out in thermostat at the temperature of $28^{\circ} \mathrm{C}$. Exposition time was selected by experimental way beginning with the middle of exponential phase of growth of bacteria X.campestris $p v$. campestris Xc2 at 4 hours interval $(8 \mathrm{~h} \pm 0.3 \mathrm{~h})$. After cultivation obtained suspensions, containing bacteriophages, were filtered with the appliance of membrane filters with pore size of 0.22 micron and determined lytic activity by Gratia method (table-6). 
It was revealed that the average optimum of the cultivation time of studied bacteriophages at the temperature of $28^{\circ} \mathrm{C}$ is within $24-28 \mathrm{hrs}$. In terms of bacteriophages $\mathrm{Kl}_{34}$-ULSAU (table-6) it was seen that within this range of considerable change of lytic activity didn't reveal, due to which as technological parameters during the production of phage preparation, we consider passage time of $24 \mathrm{hrs}$. It must be noted that during cultivation, 32 hrs of reducing lytic activity of bacteriophages is noticed.

For determination of the qualitative ratio of phage and production culture into separate test-tubes with liquid medium LB in the volume of $4.5 \mathrm{ml}$ we added $0.2 \mathrm{ml}$ of studied bacteriophage (all in 5 test tubes). Further, we added the production culture of bacteria. X.campestris $p v$. campestris Xc2 into a test tube in the concentration of 107$108 \mathrm{~m} . \mathrm{k} . / \mathrm{ml}$ in volume from 0.2 to $1 \mathrm{ml}$ at $0.2 \mathrm{ml}$ intervals (Parameters were selected experimentally). Concurrently we produced control of bacteriophages and production culture of bacteria. Further test-tubes were cultivated in a thermostat at the temperature of $28^{\circ} \mathrm{C}$ during 24 hrs. After cultivation, the content of test-tubes was filtered with the appliance of membrane filters with pore size 0.22 micron and determined lytic activity by Gratia method (table-7).

As per the results, it was established that a more optimum ratio of phage and production culture of bacteria for studied bacteriophages are1:2 and 1:3, as evidenced by submitted data in table-7. At a given ratio of phage and bacterial culture almost identical results were obtained. As optimum production parameter, the ratio of phage and bacterial culture 1:2 was chosen, as on receipt of similar results this ratioallowed to save spent recourses.

For the determination of optimum temperature parameters of the cultivation of studied bacteriophages, we added $0.2 \mathrm{ml}$ of studied bacteriophage and $0.2 \mathrm{ml}$ of culture, bacteria X.campestris pv. campestris Xc2 in concentration ofio7-108m.k./ml into test tubes with liquid medium LB in volume of $4,5 \mathrm{ml}$. Concurrently, we set a control probe of production culture and separately each of bacteriophages. Cultures were cultivated in thermostat during 24 hours at different temperature settings from $12^{\circ} \mathrm{C}$ to $36^{\circ} \mathrm{C}$ at $4^{\circ} \mathrm{C}$ intervals (parameters were selected experimentally). The results of the conducted research are shown in table- 8 . The Presence of lysis was determined by the absence of turbidity of the medium.
Conducted research showed that the range of optimum temperature of cultivation of studied bacteriophages was within $20-28^{\circ} \mathrm{C}$. Bacteriophage $\mathrm{Kl}_{34}-\mathrm{ULSAU}$ showed positive results in a range of temperatures $20-32^{\circ} \mathrm{C}$. It must be noted that after the cultivation of test tubes at $12^{\circ} \mathrm{C}$ apart from the absence of turbidity in studied test tubes, in control test tubes, this testifies the absence of culture growth at such temperature parameters.

\section{References:}

Balogh, B., Jones, J.B., Iriarte, F. B. \& Momol, M. T. (2010): Phage Therapy for Plant Disease Control. Curr. Pharm. Biotechnol., $11(1): 48-57$.

Chugunova, Î.Y. \& Tatarnikova, N.À. (2016): Appliance of bacteriophages for bacteria detection (literature review). PermAgricul. Vestnik, 4(16):121-126.

Clokie, M.R.J., Millard, A.D., Letarov, A.V. \& Heaphy, S. (2011): Phages in nature. Bacteriophage, 1(1):3-45.

Feoktistova, N.A., Vasilyev D.A., Zolotukhin C.N. \& Vasilyeva, Y.B. (2018): Modification of method of Bacillus anthracis setting phage indication in samples of soil. Asian J. Microbiol. Biotechnol. Environ. Sci., 20(3):734-737.

Francisco F.N., Gallegos, M.G., Ochoa F.Y.M., Hernández, C.F.D., Benavides, M.A. \& Castillo R.F. (2013): Fundamental aspects of common bacterial blight (Xanthomonas axonopodis $p v$. phaseoli Smith): characteristic, pathogenicity and control. Rev. Mexicana de Fitopatol. 31(2):147-160.

Ignatov, A.N., Panchuk, S.V., Ha Vo Thi Ngok, Mazurin, E.S., Kromina, K.A. \& Dzhalilov, F.S. (2016): Black rot of brassicas in Russia-epidemics, protection, and sources for resistant plants breeding. Potato Vegetables, 2:15-16.

Jones, J.B., Vallad, G.E., Iriarte, F.B., Obradovic, A., Wernsing, M.H., Jackson, L.E., Balogh, B., Hong, J.C. \& Momol, M.T. (2012): Considerations for using bacteriophages for plant disease control. Bacteriophage, 2(4):208-214.

Jensen, B.D., Vicente, J.G., Manandhar, H.K., Roberts \& S.J. (2010). Occurrence and Diversity of Xanthomonas campestris $p v$. campestris in Vegetable Brassica Fields in Nepal. Plant Dis., 94(3):298-305.

Loc-Carrillo, C. \& Abedon, S.T. (2011): Pros and cons of phage therapy. Bacteriophage, 1(2):111-114.

Massomo, S.M.S., Mortensen, C.N., Mabagala, R.B., Newman, M.A. \& Hockenhull, J. (2004): Biological Control of Black Rot (Xanthomonas campestris pv. campestris) of Cabbage in Tanzania with Bacillus strains. L. Phytopathol., 152(2): 98 - 105.

Renu, Bhoyar, M.S., Singh, U.B., Sahu, U. Nagrale, D.T. \& Sahu, P.K. (2017): Characterization of lytic bacteriophage xcc9sh3. I. Plant Pathol., 99(1):233-238. 